\title{
Implementasi ARAS Melalui Pendekatan Interpolasi Linier pada Penyeleksian Peserta Magang
}

\author{
Dita Amara, Dwi Kartini, Andi Farmadi, Muliadi, Irwan Budiman \\ Program Studi Ilmu Komputer, Fakultas Matematika dan Ilmu Pengetahuan Alam, Universitas \\ Lambung Mangkurat \\ Banjarbaru, Kalimantan Selatan, Indonesia, telp. (0511) 4773112 \\ e-mail: ditaamara1409@gmail.com, dwikartini@ulm.ac.id, andifarmadi@ulm.ac.id, \\ muliadi@ulm.ac.id, irwan.budiman@ulm.ac.id
}

\begin{abstract}
Abstrak
Penyeleksian peserta magang umumnya masih dilakukan secara manual, dilakukan dengan membandingkan keseluruhan data para pendaftar yang memenuhi setiap persyaratan berdasarkan urutan kepentingan persyaratan yang ditentukan oleh penyelenggara magang tersebut. Hasil keputusan pendaftar yang dinyatakan diterima didapatkan berdasarkan urutan penilaian para pendaftar dari yang tertinggi sesuai dengan kuota yang diperlukan pada setiap periodenya. Interpolasi Linier digunakan dengan melakukan penyetaraan skala nilai yang berbeda pada kriteria nilai kelulusan berdasarkan strata kelulusannya. Rank Order Centroid (ROC) digunakan untuk memberikan nilai input kriteria strata kelulusan dan bobot kriteria, yaitu bobot untuk kriteria komunikasi 0,33973, sikap 0,21473, penampilan 0,15223, kecakapan 0,11057, tinggi badan 0,07932, strata kelulusan 0,05432, nilai kelulusan 0,03348, dan usia 0,01563. Additive Ratio Assessment (ARAS) digunakan untuk mendapatkan perankingan alternatif yang dijadikan sebagai pertimbangan dalam memutuskan pendaftar diterima atau tidak. Hasil penelitian diperoleh nilai kemiripan antara hasil keputusan menggunakan metode ARAS dan hasil keputusan penyelenggara magang berdasarkan perhitungan accuracy yang didapatkan dari Confusion Matrix adalah 91,453\%.
\end{abstract}

Kata kunci: Additive Ratio Assessment, Confusion Matrix, Interpolasi Linier, Magang, Rank Order Centroid

\section{Abstract}

The selection of internsip participant is generally still done manually by comparing the overall data of the candidates who have met each requirement based on priority level of the requirements determined by the internship organizer. The result of the candidates which were accepted was obtained based on the order of assessment of the candidates from the highest according to the quota required in each period. Linear Interpolation is used by equalizing different value scales on graduation score criteria based on graduation level. Rank Order Centroid $(R O C)$ is used to determine input values of graduation levels criteria and weights for each criterion, the weight of communication criteria 0,33973, attitude criteria 0,21473, appearance criteria 0,15223, skill criteria 0,11057, height criteria 0,07932, graduation level criteria 0,05432, graduation score criteria 0,03348, and age criteria 0,01563. Additive Ratio Assessment (ARAS) is used to get an alternative ranking which is used as a consideration for candidates to be accepted or not. The result of this research is that the similarity between the decision results using the ARAS method and the decision of the internship organizer based on the accuracy calculation obtained from the Confusion Matrix is $91,453 \%$.

Keywords : Additive Ratio Assessment, Confusion Matrix, Interpolasi Linier, Internship, Rank Order Centroid

\section{Pendahuluan}

Penyeleksian peserta magang di BNI KCU Kotabaru P. Laut masih dilakukan secara manual, dengan membandingkan data para pendaftar yang telah memenuhi setiap persyaratan berdasarkan urutan kepentingan persyaratan yang ditetapkan oleh penyelenggara magang. Persyaratan/kriteria terdiri dari komunikasi, sikap, penampilan, kecakapan, tinggi badan, strata 
kelulusan, nilai kelulusan, dan usia. Kriteria nilai kelulusan terdapat perbedaan skala nilai, karena jenjang strata kelulusan yang berbeda-beda. Pendaftar dinyatakan diterima berdasarkan urutan penilaian pendaftar dari yang tertinggi sesuai dengan kuota pada setiap periode.

Ada beberapa penelitian yang membahas mengenai urutan sistem pemilihan secara manual, seperti dalam bidang kesehatan, pariwisata, dan pemerintahan. Penelitian dalam bidang kesehatan mengenai penerapan sistem pemilihan FIFO pada sistem antrean pelayanan medis praktik dokter bersama [1]. Sistem antrean berbasis web dibuat menggunakan sistem pemilihan FIFO, yaitu pasien dengan nomor antrean lebih awal mendapatkan pelayanan medis terlebih dahulu. Sistem yang dihasilkan mempermudah administrasi sehingga meminimalkan kesalahan data dan menghemat waktu. Penelitian dalam bidang pariwisata mengenai metode TOPSIS pada sistem informasi geografis rekomendasi objek wisata Bali [2]. Metode TOPSIS dalam bentuk sistem informasi geografis digunakan untuk memberikan rekomendasi objek wisata yang paling sesuai dan menampilkan informasi objek wisata, rute perjalanan, dan paket wisata. Hasil evaluasi kepuasan pengguna untuk aspek tampilan sistem $83,67 \%$, kualitas sistem $84,33 \%$, kualitas informasi $82,67 \%$, dan fungsionalitas sistem $85,67 \%$, dimana sistem dapat memudahkan pencarian informasi objek wisata yang ada di Bali. Penelitian dalam bidang pemerintahan mengenai teknologi smart card sebagai kartu pemilih pada sistem Pilkades [3]. Teknologi smart card sebagai kartu pemilih dengan media sistem e-voting digunakan dalam sistem Pilkades yang dipasang pada komputer, dimana reader/writer tools sebagai media untuk membaca/menulis pada smart card. Penelitian ini berhasil menerapkan sistem e-voting pilkades yang menunjukkan penghematan waktu dan tenaga sumber daya terutama dalam proses perhitungan suara.

Penelitian sebelumnya telah dilakukan mengenai metode Analytic Hierarchy Process (AHP), Simple Additive Weighting (SAW), dan ROC pada penentuan pemberian beasiswa di STIKI [4]. ROC digunakan untuk menentukan nilai bobot data tingkat kejuaraan dan bidang kejuaraan. Interpolasi Linier digunakan untuk mengubah nilai dari data penghasilan orang tua dan daya listrik. Hasil penelitian menunjukkan bahwa alternatif terbaik antara perhitungan sistem, perhitungan manual, dan perhitungan yang dilakukan pada STIKI adalah alternatif yang sama. Penelitian lainnya membandingkan 4 metode pembobotan pengambilan keputusan berbasis peringkat [5]. Data yang digunakan adalah data pemilihan mobil yang didapatkan dengan mengambil sampel 16 mahasiswa pascasarjana jurusan teknik industry. Hasil perbandingan menunjukkan bahwa metode ROC memberikan persentase tertinggi, yaitu $81,2 \%$. ROC cenderung terbaik, karena kecuraman dan fungsi non-linier yang sesuai dengan Sebagian besar Tindakan pengambil keputusan. Metode ARAS pernah diteliti pada penentuan kredit simpan pinjam [6]. ARAS digunakan untuk mendapatkan perankingan alternatif dengan bobot yang langsung ditentukan oleh pengambil keputusan. Diperoleh tingkat kesesuaian menggunakan korelasi Rank Spearman antara ranking dari implementasi metode ARAS dengan ranking dari koperasi yaitu 0,8571 .

Penelitian penyeleksian peserta magang ini menggunakan metode ROC untuk mendapatkan nilai bobot setiap kriteria dan metode ARAS untuk perankingan alternatif. Pendekatan Interpolasi Linier untuk normalisasi data kriteria nilai kelulusan. Perbandingan hasil penelitian dilakukan dengan pengujian menggunakan Confusion Matrix untuk mengetahui nilai akurasinya.

\section{Metodologi Penelitian}

Adapun metodologi penelitian dalam penelitian ini, yaitu pertama-tama melakukan identifikasi masalah dengan mengumpulkan berbagai informasi terkait kebutuhan penelitian dengan melakukan studi literatur dengan cara mempelajari bahan penelitian, seperti dari buku dan internet, serta melakukan wawancara dengan penyelenggara magang tersebut mengenai detail penelitian ini. Kedua, mengumpulkan dan menganalisis data yang berhubungan dengan penyeleksian peserta magang, yaitu data kriteria yang digunakan beserta tingkat prioritas kriteria yang telah ditentukan oleh penyelenggara magang, data pendaftar, dan data hasil keputusan dari penyelenggara magang. Pada data pendaftar untuk kriteria nilai kelulusan, terdapat perbedaan skala nilai, karena strata kelulusan yang berbeda-beda. Sehingga, Interpolasi Linier digunakan untuk menyetarakan nilai yang berbeda skala tersebut. Selain itu, ROC juga digunakan untuk memberikan nilai input pada data kriteria strata kelulusan. Ketiga, mengimplementasikan langkah-langkah pembobotan ROC pada data kriteria yang digunakan. Keempat, Mengimplementasikan langkah-langkah ARAS pada data pendaftar sesuai dengan 
kriteria yang digunakan dengan nilai bobot kriteria yang didapatkan dari hasil perhitungan menggunakan pembobotan ROC. Terakhir, mengevaluasi hasil dengan menghitung nilai kemiripan keputusan penyeleksian menggunakan metode terhadap keputusan penyelenggara magang menggunakan Confusion Matrix.

\section{Kajian Pustaka}

Kajian pustaka yang digunakan berupa referensi yang terkait dengan penelitian ini, yaitu mengenai Interpolasi Linier, Rank Order Centroid (ROC), dan Additive Ratio Assessment (ARAS).

\subsection{Interpolasi Linier}

Interpolasi linier merupakan cara memperkirakan suatu fungsi pendekatan atau fungsi analitik yang tidak diketahui dari fungsi yang telah diketahui atau pengganti fungsi kompleks yang tidak diketahui fungsi analitiknya [7]. Bila diketahui dua titik, maka titik diantara dua titik tersebut menggunakan pendekatan garis lurus, dapat dihitung menggunakan Persamaan 1.

$y-y_{1}=\frac{y_{2}-y_{1}}{x_{2}-x_{1}}\left(x-x_{1}\right)$

Dimana, $x_{1}$ adalah batas bawah nilai awal, $x_{2}$ adalah batas atas nilai awal, $y_{1}$ adalah batas bawah nilai akhir, $y_{2}$ adalah batas atas nilai akhir, $x$ adalah nilai awal yang diketahui, dan $y$ adalah nilai akhir yang dicari.

\subsection{Rank Order Centroid (ROC)}

Rank Order Centroid (ROC) dipertimbangkan dalam beberapa analisis kontekstual, karena kualitas dan kesederhanaan dalam proses pemberian bobot [8]. Pengambil keputusan harus mengurutkan kriteria berdasarkan kepentingannya. ROC memberikan bobot setiap kriteria sesuai tingkat prioritas kepentingan yang telah ditentukan pengambil keputusan [9]. Dibentuk dengan pernyataan "Kriteria 1 lebih penting dari kriteria 2, yang lebih penting dari kriteria 3" dan seterusnya hingga kriteria ke-n. Metode pembobotan ROC dapat menghasilkan bobot sesuai proporsi yang tepat pada setiap kriteria. Untuk menentukan nilai bobot menggunakan Persamaan 2.

$W=\frac{1}{k} \sum_{i=1}^{k}\left(\frac{1}{i}\right)$

Dimana, $W$ merupakan nilai bobot, $k$ adalah jumlah datanya, dan i adalah tingkat prioritasnya.

\subsection{Additive Ratio Assessment (ARAS)}

Menurut ARAS, suatu nilai fungsi utilitas menentukan ketepatgunaan dari alternatif yang sebanding dengan pengaruh relatif nilai dan bobot kriteria yang dipertimbangkan [10]. Tingkat utilitas alternatif ditentukan oleh perbandingan varian dengan yang optimal. Langkahlangkah dalam metode ARAS adalah:

1. Pembentukan Matriks Keputusan

$$
X=\left[\begin{array}{ccccc}
x_{01} & \ldots & x_{0 j} & \ldots & x_{0 n} \\
\ldots & \ldots & \ldots & \ldots \\
x_{i 1} & \ldots & x_{i j} & \ldots & x_{i n} \\
\ldots & \ldots & \ldots & \ldots \\
x_{m 1} & \ldots & x_{m j} & \ldots & x_{m n}
\end{array}\right]
$$

Persamaan 3 adalah matriks keputusan, dimana $X$ adalah matriks keputusan, $m$ adalah jumlah alternatif, $n$ adalah jumlah kriteria pada setiap alternatif, nilai $x_{i j}$ mewakili nilai alternatif $i$ dalam kriteria $j, x_{0 j}$ adalah nilai optimal dari kriteria $j$. Persamaan 4 digunakan untuk menentukan nilai optimal setiap kriteria pada alternatif optimal.

$x_{0 j}=\max x_{i j}, j$ jika $\max x_{i j}$ lebih baiks

$x_{0 j}=\min x *_{i j}$ jjika min $x^{*} i j$ lebih baik 
2. Normalisasi Matriks Keputusan

Matriks keputusan harus dinormalisasi menjadi skala yang dapat dibandingkan. Kriteria dengan ketentuan nilai maksimal yang lebih baik, dinormalisasi menggunakan Persamaan 5.

$\bar{x}_{i j}=\frac{x_{i j}}{\sum_{i=0}^{m} x_{i j}}$

Kriteria dengan ketentuan nilai minimal yang lebih baik, dinormalisasi menggunakan Persamaan 6.

$x_{i j}=\frac{1}{x^{*} i j} ; \bar{x}_{i j}=\frac{x_{i j}}{\sum_{i=0}^{m} x_{i j}}$

Dimana, $\bar{x}_{i j}$ adalah matrik keputusan ternormalisasi.

3. Matriks Keputusan Ternormalisasi Terbobot Jumlah bobot dibatasi seperti Persamaan 7.

$\sum_{j=1}^{n} w_{j}=1$

Nilai normalisasi terbobot dari semua kriteria yang ada dihitung menggunakan Persamaan 8.

$x_{i j}=\bar{x}_{i j} w_{j}$

Dimana, $w_{j}$ adalah bobot kriteria $j$ dan $\bar{x}_{i j}$ adalah nilai yang telah dinormalisasi.

4. Menghitung Nilai Fungsi Optimalitas

$S_{i}=\sum_{j=1}^{n} x_{i j}$

Persamaan 9 merupakan persamaan untuk menghitung nilai fungsi optimalitas, dimana $S_{i}$ adalah nilai fungsi optimalitas dari alternatif $i$.

5. Menghitung Tingkat Utilitas

Semakin besar nilai fungsi optimalitas $S_{i}$, semakin efektif alternatifnya. Tingkat utilitas alternatif ditentukan oleh perbandingan varian dengan yang paling optimal. Persamaan 10 digunakan untuk perhitungan tingkat utilitas (utility degree):

$K_{i}=\frac{s_{i}}{s_{0}}$

Dimana, $K_{\mathrm{i}}$ adalah tingkat utilitas alternatif untuk alternatif $i$.

\section{Hasil dan Pembahasan}

Hasil dan pembahasan pada penelitian ini terdiri dari Interpolasi Linier untuk penyetaraan nilai data kriteria nilai kelulusan yang berbeda skala, $\mathrm{ROC}$ untuk menentukan nilai input data kriteria strata kelulusan berdasarkan masing-masing jenjang strata kelulusan, ROC untuk nilai bobot setiap kriteria, ARAS untuk mendapatkan perankingan alternatif dari penyeleksian magang, dan evaluasi hasil keputusan menggunakan Confusion Matrix.

\subsection{Interpolasi Linier pada Data Kriteria Nilai Kelulusan}

Interpolasi Linier digunakan untuk menyetarakan nilai yang skalanya berbeda pada data kriteria nilai kelulusan pendaftar. Hal tersebut dilakukan agar data dapat dibandingkan satu dengan yang lainnya. Nilai dengan skala 7 sampai dengan 10 diubah menjadi skala 2,5 sampai dengan 4. Data kriteria nilai kelulusan para pendaftar dapat dilihat pada Tabel 1.

Tabel 1. Data Kriteria Nilai Kelulusan Pendaftar

\begin{tabular}{cc}
\hline No. Tes & Nilai Kelulusan \\
\hline BNI1901001 & 3,26 \\
\hline
\end{tabular}




\begin{tabular}{lc}
\hline BNI1901002 & 8,5 \\
BNI1901003 & 3,23 \\
BNI1901004 & 3,37 \\
BNI1901005 & 3,18 \\
BNI1901006 & 2,83 \\
BNI1901007 & 3,21 \\
BNI1901008 & 3,11 \\
BNI1901009 & 7,1 \\
BNI1901010 & 7,8 \\
BNI1901011 & 3,39 \\
BNI1901012 & 3,21 \\
BNI1901013 & 8,4 \\
BNI1901014 & 3,04 \\
BNI1901015 & 8 \\
BNI1901016 & 8,8 \\
BNI1901017 & 8,5 \\
BNI1901018 & 7,5 \\
BNI1901019 & 3,54 \\
BNI1901020 & 8,2 \\
BNI1901021 & 7,6 \\
BNI1901022 & 7,7 \\
BNI1901023 & 3,75 \\
BNI1901024 & 7,6 \\
BNI1901025 & 3.22 \\
$\ldots$ & $\ldots$ \\
BNI1901117 & 8 \\
\hline
\end{tabular}

Perhitungan menggunakan Persamaan 1 untuk seluruh nilai kelulusan pendaftar yang memiliki skala nilai 7 sampai dengan 10 agar setara dengan nilai berskala 2,5 sampai dengan 4. Dengan ketentuan:

$$
\begin{aligned}
& x_{1}=7 ; \quad x_{2}=10 \\
& y_{1}=2,5 ; \quad y_{2}=4
\end{aligned}
$$

Perhitungan data No. Tes BNI1901002.

$x=8,5$

$$
y-2,5=\frac{4-2,5}{10-7}(8,5-7)=3,25
$$

Hasil perhitungan nilai kelulusan pendaftar menggunakan Interpolasi Linier yang dapat dilihat pada Tabel 2.

Tabel 2. Data Nilai Kelulusan Menggunakan Interpolasi Linier

\begin{tabular}{cc}
\hline No. Tes & Nilai Kelulusan \\
\hline BNI1901001 & 3,26 \\
BNI1901002 & 3,25 \\
BNI1901003 & 3,23 \\
BNI1901004 & 3,37 \\
BNI1901005 & 3,18 \\
BNI1901006 & 2,83 \\
BNI1901007 & 3,21 \\
BNI1901008 & 3,11 \\
BNI1901009 & 2,55 \\
BNI1901010 & 2,9 \\
BNI1901011 & 3,39 \\
BNI1901012 & 3,21 \\
BNI1901013 & 3,2 \\
\hline
\end{tabular}




\begin{tabular}{cc}
\hline BNI1901014 & 3,04 \\
BNI1901015 & 3 \\
BNI1901016 & 3,4 \\
BNI1901017 & 3,25 \\
BNI1901018 & 2,75 \\
BNI1901019 & 3,54 \\
BNI1901020 & 3,1 \\
BNI1901021 & 2,8 \\
BNI1901022 & 2,85 \\
BNI1901023 & 3,75 \\
BNI1901024 & 2,8 \\
$\ldots$ & $\ldots$ \\
BNI1901117 & 3 \\
\hline
\end{tabular}

\subsection{Rank Order Centroid (ROC) pada Data Kriteria Strata Kelulusan}

ROC digunakan salah satunya untuk menentukan nilai input SMA, Diploma, dan S-1 pada kriteria strata kelulusan. Tingkat prioritas strata kelulusan yang telah ditetapkan oleh penyelenggara magang yang dapat dilihat pada Tabel 3 .

\begin{tabular}{cc}
\multicolumn{2}{c}{ Tabel 3. Data Kriteria Strata Kelulusan } \\
\hline Strata Kelulusan & Tingkat Prioritas \\
\hline S-1 & 1 \\
Diploma & 2 \\
SMA & 3 \\
\hline
\end{tabular}

Perhitungan ROC menggunakan Persamaan 2 ditentukan berdasarkan tingkat prioritas dan jumlah datanya pada 3 strata kelulusan beserta masing-masing tingkat prioritasnya.

Perhitungan nilai input untuk strata kelulusan S-1.

$W_{1}=\frac{1+\frac{1}{2}+\frac{1}{3}}{3}=0,61111$

Hitung semua data kriteria stara kelulusan menggunakan Persamaan 2 untuk mendapatkan nilai input-nya. Nilai input dari hasil perhitungan dapat dilihat pada Tabel 4.

Tabel 4. Nilai Input Kriteria Strata Kelulusan

\begin{tabular}{cc}
\hline Strata Kelulusan & Nilai Input \\
\hline S-1 & 0,61111 \\
Diploma & 0,27778 \\
SMA & 0,11111 \\
\hline
\end{tabular}

\subsection{Rank Order Centroid (ROC) untuk Nilai Bobot Kriteria}

ROC digunakan untuk menentukan nilai bobot setiap kriteria. Tingkat prioritas nilai setiap kriteria telah ditetapkan oleh penyelenggara magang yang dapat dilihat pada Tabel 5.

Tabel 5. Data Kriteria

\begin{tabular}{cc}
\hline Kriteria & Tingkat Prioritas \\
\hline Komunikasi & 1 \\
Sikap & 2 \\
Penampilan & 3 \\
Kecakapan & 4 \\
Tinggi Badan & 5 \\
Strata Kelulusan & 6 \\
Nilai Kelulusan & 7 \\
Usia & 8 \\
\hline
\end{tabular}


Penyeleksian magang terdiri dari 8 kriteria yang digunakan beserta masing-masing tingkat prioritasnya. Hasil perhitungan untuk mendapatkan nilai bobot kriteria menggunakan Persamaan 2 dapat dilihat pada Tabel 6.

Tabel 6. Nilai Bobot Kriteria

\begin{tabular}{ccc}
\hline Kriteria & Tingkat Prioritas & Bobot Kriteria \\
\hline Komunikasi & 1 & 0,33973 \\
Sikap & 2 & 0,21473 \\
Penampilan & 3 & 0,15223 \\
Kecakapan & 4 & 0,11057 \\
Tinggi Badan & 5 & 0,07932 \\
Strata Kelulusan & 6 & 0,05432 \\
Nilai Kelulusan & 7 & 0,03348 \\
Usia & 8 & 0,01563 \\
\hline
\end{tabular}

\subsection{Additive Ratio Assessment (ARAS) untuk Perankingan Alternatif}

Penyetaraan nilai yang berbeda skala pada data kriteria nilai kelulusan menggunakan Interpolasi Linier, menentukan nilai input pada data kriteria strata kelulusan dan bobot untuk kriteria menggunakan ROC. Perhitungan menggunakan ARAS untuk mendapatkan perankingan alternatif sebagai pertimbangan untuk menentukan pendaftar yang diterima dan tidak diterima menjadi peserta magang berdasarkan kuota yang ditetapkan oleh penyelenggara magang.

1. Pembentukan Matriks Keputusan

Nilai kriteria tinggi badan, terdapat perbedaan minimal tinggi badan setiap jenis kelamin, yaitu untuk perempuan $155 \mathrm{~cm}$ dan laki-laki $165 \mathrm{~cm}$, maka dilakukan perhitungan dengan menggunakan selisih tinggi badan dengan standar minimal berdasarkan jenis kelamin. Semua kriteria bersifat benefit (semakin maksimal semakin baik), dimana untuk menentukan nilai optimal kriteria benefit menggunakan Persamaan 4 dan pembentukan matriks keputusan menggunakan Persamaan 3 dapat dilihat pada Tabel 7.

Tabel 7. Nilai Bobot Kriteria

\begin{tabular}{|c|c|c|c|c|c|c|c|c|}
\hline No. Tes & $\begin{array}{l}\text { Tinggi } \\
\text { Badan }\end{array}$ & $\begin{array}{c}\text { Strata } \\
\text { Kelulusan }\end{array}$ & $\begin{array}{c}\text { Nilai } \\
\text { Kelulusan }\end{array}$ & Usia & $\begin{array}{l}\text { Komu } \\
\text { nikasi }\end{array}$ & Sikap & $\begin{array}{l}\text { Penam } \\
\text { pilan }\end{array}$ & $\begin{array}{c}\text { Kecaka } \\
\text { pan }\end{array}$ \\
\hline Optimal & 15 & 0,61111 & 3,75 & 24 & 3 & 3 & 4 & 4 \\
\hline BNI1901001 & 2 & 0,61111 & 3,26 & 22 & 3 & 3 & 3 & 3 \\
\hline BNI1901002 & 1 & 0,11111 & 3,25 & 24 & 3 & 3 & 3 & 3 \\
\hline BNI1901003 & 3 & 0,61111 & 3,23 & 23 & 3 & 3 & 3 & 3 \\
\hline BNI1901004 & 3 & 0,61111 & 3,37 & 22 & 3 & 3 & 3 & 3 \\
\hline BNI1901005 & 3 & 0,61111 & 3,18 & 22 & 3 & 3 & 3 & 3 \\
\hline BNI1901006 & 8 & 0,61111 & 2,83 & 24 & 3 & 3 & 3 & 3 \\
\hline BNI1901007 & 14 & 0,61111 & 3,21 & 23 & 3 & 3 & 3 & 2 \\
\hline BNI1901008 & 2 & 0,61111 & 3,11 & 24 & 3 & 3 & 3 & 3 \\
\hline BNI1901009 & 1 & 0,11111 & 2,55 & 21 & 3 & 3 & 4 & 4 \\
\hline BNI1901010 & 8 & 0,11111 & 2,9 & 18 & 3 & 3 & 3 & 3 \\
\hline BNI1901011 & 9 & 0,61111 & 3,39 & 22 & 3 & 3 & 3 & 2 \\
\hline BNI1901012 & 3 & 0,27778 & 3,21 & 21 & 3 & 3 & 4 & 3 \\
\hline BNI1901013 & 4 & 0,11111 & 3,2 & 19 & 3 & 3 & 3 & 4 \\
\hline BNI1901014 & 5 & 0,61111 & 3,04 & 23 & 3 & 3 & 3 & 3 \\
\hline BNI1901015 & 3 & 0,11111 & 3 & 21 & 3 & 3 & 3 & 3 \\
\hline BNI1901016 & 1 & 0,11111 & 3,4 & 23 & 3 & 3 & 3 & 4 \\
\hline BNI1901017 & 4 & 0,11111 & 2,35 & 19 & 3 & 3 & 3 & 3 \\
\hline BNI1901018 & 1 & 0,11111 & 2,75 & 18 & 3 & 3 & 4 & 4 \\
\hline BNI1901019 & 4 & 0,61111 & 3,54 & 23 & 2 & 3 & 3 & 3 \\
\hline BNI1901020 & 4 & 0,11111 & 3,1 & 18 & 3 & 3 & 3 & 2 \\
\hline BNI1901021 & 2 & 0,11111 & 2,8 & 21 & 3 & 3 & 3 & 3 \\
\hline BNI1901022 & 7 & 0,11111 & 2,85 & 19 & 3 & 3 & 3 & 2 \\
\hline BNI1901023 & 6 & 0,27778 & 3,75 & 21 & 2 & 3 & 3 & 3 \\
\hline
\end{tabular}




\begin{tabular}{ccccccccc}
\hline BNI1901024 & 15 & 0,11111 & 2,8 & 20 & 2 & 3 & 3 & 3 \\
$\ldots$ & $\ldots$ & $\ldots$ & $\ldots$ & $\ldots$ & $\ldots$ & $\ldots$ & $\ldots$ & $\ldots$ \\
BNI1901117 & 6 & 0,11111 & 3 & 19 & 3 & 3 & 3 & 2 \\
\hline
\end{tabular}

2. Normalisasi Matriks Keputusan

Normalisasi matriks keputusan menggunakan Persamaan 5, karena semua kriteria bersifat nilai maksimal yang lebih baik.

Perhitungan data No. Tes BNI1901001.

$\bar{x}_{11}=\frac{2}{426}=0,00469$

$\bar{x}_{12}=\frac{0,61111}{38,11107}=0,01603$

$\bar{x}_{1 \mathrm{a}}=\frac{3,26}{375,17000}=0,00869$

$\bar{x}_{14}=\frac{22}{2507}=0,00878$

$\bar{x}_{15}=\frac{3}{290}=0,01034$

$\bar{x}_{16}=\frac{3}{354}=0,00847$

$\bar{x}_{17}=\frac{3}{360}=0,00833$

$\bar{x}_{18}=\frac{3}{336}=0,00893$

Hitung normalisasi untuk seluruh alternatif.

3. Matriks Keputusan Ternormalisasi Terbobot

Perhitungan matriks keputusan ternormalisasi terbobot menggunakan Persamaan 8 , dimana nilai bobot yang digunakan untuk setiap kriteria telah didapatkan dari hasil perhitungan nilai bobot kriteria menggunakan pembobotan ROC dengan jumlah bobot yang digunakan yaitu 1 sesuai dengan Persamaan 7 .

Perhitungan data No. Tes BNI1901001.

$x_{11}=0,00469 \times 0,07932=0,00037$

$x_{12}=0,01603 \times 0,05432=0,00087$

$x_{13}=0,00869 \times 0,03348=0,00029$

$x_{14}=0,00878 \times 0,01563=0,00014$

$x_{15}=0,01034 \times 0,33973=0,00351$

$x_{16}=0,00847 \times 0,21473=0,00182$

$x_{17}=0,00833 \times 0,15223=0,00127$

$x_{18}=0,00893 \times 0,11057=0,00099$

Hitung untuk seluruh alternatif. 
4. Menghitung Nilai Fungsi Optimalitas

Perhitungan nilai fungsi optimalitas untuk seluruh alternatif menggunakan Persamaan 9 yang hasil perhitungannya dapat dilihat pada Tabel 8.

Tabel 8. Nilai Fungsi Optimalitas Alternatif

\begin{tabular}{cc}
\hline No. Tes & S \\
\hline Optimal & 0,01249 \\
BNI1901001 & 0,00927 \\
BNI1901002 & 0,00837 \\
BNI1901003 & 0,00945 \\
BNI1901004 & 0,00946 \\
BNI1901005 & 0,00944 \\
BNI1901006 & 0,01035 \\
BNI1901007 & 0,01117 \\
BNI1901008 & 0,00926 \\
BNI1901009 & 0,00905 \\
BNI1901010 & 0,00961 \\
BNI1901011 & 0,01025 \\
BNI1901012 & 0,00938 \\
BNI1901013 & 0,00923 \\
BNI1901014 & 0,00981 \\
BNI1901015 & 0,00870 \\
BNI1901016 & 0,00871 \\
BNI1901017 & 0,00890 \\
BNI1901018 & 0,00904 \\
BNI1901019 & 0,00849 \\
BNI1901020 & 0,00855 \\
BNI1901021 & 0,00850 \\
BNI1901022 & 0,00910 \\
BNI1901023 & 0,00840 \\
BNI1901024 & 0,00974 \\
$\ldots$ & $\ldots$ \\
BNI1901117 & 0,00892 \\
\hline &
\end{tabular}

5. Menghitung Tingkat Utilitas

Perhitungan tingkat utilitas untuk seluruh alternatif menggunakan Persamaan 10 agar mendapatkan perankingan alternatif, dimana perankingan alternatif tersebut dapat digunakan untuk menentukan pendaftar yang diterima dan tidak diterima. Penyeleksian magang kali ini, pendaftar yang diterima berjumlah 18 orang, selain itu dinyatakan tidak diterima. 18 orang pendaftar yang diterima tersebut didapatkan berdasarkan urutan ranking tertinggi. Hasil keputusan berdasarkan perankingan alternatif yang didapatkan dari perhitungan menggunakan ARAS yang dapat dilihat pada Tabel 9.

Tabel 9. Tingkat Utilitas Alternatif

\begin{tabular}{cccc}
\hline No. Tes & K & Ranking & Hasil Metode \\
\hline Optimal & 1,00000 & & \\
BNI1901001 & 0,74150 & 12 & Diterima \\
BNI1901002 & 0,67046 & 49 & Tidak Diterima \\
BNI1901003 & 0,75669 & 9 & Diterima \\
BNI1901004 & 0,75719 & 8 & Diterima \\
BNI1901005 & 0,75584 & 10 & Diterima \\
BNI1901006 & 0,82887 & 2 & Diterima \\
BNI1901007 & 0,89419 & 1 & Diterima \\
BNI1901008 & 0,74143 & 13 & Diterima \\
BNI1901009 & 0,72417 & 18 & Diterima \\
BNI1901010 & 0,76932 & 7 & Diterima \\
BNI1901011 & 0,82044 & 3 & Diterima \\
BNI1901012 & 0,75137 & 11 & Diterima \\
\hline
\end{tabular}




\begin{tabular}{cccc}
\hline BNI1901013 & 0,73868 & 14 & Diterima \\
BNI1901014 & 0,78515 & 4 & Diterima \\
BNI1901015 & 0,69700 & 29 & Tidak Diterima \\
BNI1901016 & 0,69738 & 27 & Tidak Diterima \\
BNI1901017 & 0,71269 & 22 & Tidak Diterima \\
BNI1901018 & 0,72410 & 19 & Tidak Diterima \\
BNI1901019 & 0,68002 & 44 & Tidak Diterima \\
BNI1901020 & 0,68477 & 37 & Tidak Diterima \\
BNI1901021 & 0,68066 & 43 & Tidak Diterima \\
BNI1901022 & 0,72821 & 15 & Diterima \\
BNI1901023 & 0,67230 & 47 & Tidak Diterima \\
BNI1901024 & 0,78016 & 5 & Diterima \\
$\ldots$ & $\ldots$ & $\ldots$ & $\ldots$ \\
BNI1901117 & 0,71437 & 21 & Tidak Diterima \\
\hline
\end{tabular}

\subsection{Evaluasi Hasil}

Hasil perbandingan antara hasil keputusan yang didapatkan menggunakan metode dengan hasil keputusan dari penyelenggara magang dapat dilihat pada Tabel 10.

Tabel 10. Perbandingan Hasil Keputusan

\begin{tabular}{ccc}
\hline No. Tes & Hasil Metode & Penyelenggara Magang \\
\hline BNI1901001 & Diterima & Diterima \\
BNI1901002 & Tidak Diterima & Diterima \\
BNI1901003 & Diterima & Diterima \\
BNI1901004 & Diterima & Diterima \\
BNI1901005 & Diterima & Diterima \\
BNI1901006 & Diterima & Diterima \\
BNI1901007 & Diterima & Diterima \\
BNI1901008 & Diterima & Diterima \\
BNI1901009 & Diterima & Diterima \\
BNI1901010 & Diterima & Diterima \\
BNI1901011 & Diterima & Diterima \\
BNI1901012 & Diterima & Diterima \\
BNI1901013 & Diterima & Diterima \\
BNI1901014 & Diterima & Diterima \\
BNI1901015 & Tidak Diterima & Diterima \\
BNI1901016 & Tidak Diterima & Diterima \\
BNI1901017 & Tidak Diterima & Diterima \\
BNI1901018 & Tidak Diterima & Diterima \\
BNI1901019 & Tidak Diterima & Tidak Diterima \\
BNI1901020 & Tidak Diterima & Tidak Diterima \\
BNI1901021 & Tidak Diterima & Tidak Diterima \\
BNI1901022 & Diterima & Tidak Diterima \\
BNI1901023 & Tidak Diterima & Tidak Diterima \\
BNI1901024 & Diterima & Tidak Diterima \\
$\ldots$ & $\ldots \ldots$ & $\ldots$ \\
BNI1901117 & Tidak Diterima & Tidak Diterima \\
\hline
\end{tabular}

Confusion Matrix dikenal sebagai proses pengujian yang merepresentasikan hasil penggunaan metode [11]. Tabel Confusion Matrix dapat dilihat pada Tabel 11.

Tabel 11. Confusion Matrix

\begin{tabular}{|l|l|l|l|}
\hline \multicolumn{2}{|c|}{ Confusion Matrix } & \multicolumn{2}{c|}{ Predicted } \\
\cline { 3 - 4 } & Positive & Negative \\
\hline \multirow{2}{*}{ Actual } & Positive & True Positive & False Negative \\
\cline { 2 - 4 } & Negative & False Positve & True Negative \\
\hline
\end{tabular}


True Positive (TP) menunjukkan bahwa dokumen yang termasuk kelas positif dalam hasil pengelompokkan sistem memang anggota kelas positif. False Positive (FP) menunjukkan bahwa dokumen yang termasuk kelas positif dalam hasil pengelompokkan oleh sistem ternyata bukan merupakan anggota kelas positif. False Negative (FN) menunjukkan bahwa dokumen yang tidak termasuk kelas positif dalam hasil pengelompokkan oleh sistem ternyata merupakan anggota kelas positif. True Negative (TN) menunjukkan bahwa dokumen yang tidak termasuk kelas positif dalam hasil pengelompokkan oleh sistem memang bukan anggota kelas positif.

Confusion Matrix dari kedua hasil keputusan penyeleksian magang dapat dilihat pada Tabel 12.

Tabel 12. Confusion Matrix Hasil Keputusan

\begin{tabular}{|c|l|l|l|}
\hline \multicolumn{2}{|c|}{ Confusion Matrix } & \multicolumn{2}{c|}{ Predicted } \\
\cline { 3 - 4 } & Positive & Negative \\
\hline \multirow{2}{*}{ Actual } & Positive & 13 & 5 \\
\cline { 2 - 4 } & Negative & 5 & 94 \\
\hline
\end{tabular}

Ada 13 data menyatakan bahwa penyelenggara magang dan hasil perhitungan menggunakan metode memberikan keputusan pendaftar tersebut diterima. 94 data menyatakan bahwa penyelenggara magang dan hasil perhitungan menggunakan metode memberikan keputusan pendaftar tersebut tidak diterima. 5 data menyatakan bahwa penyelenggara magang memberikan keputusan pendaftar tersebut tidak diterima, tetapi hasil perhitungan menggunakan metode memberikan keputusan pendaftar tersebut diterima. 5 data menyatakan bahwa penyelenggara magang memberikan keputusan pendaftar tersebut diterima, tetapi hasil perhitungan menggunakan metode memberikan pendaftar tersebut tidak diterima.

Evaluasi Confusion Matrix hasil keputusan, dapat dilakukan perhitungan Accuracy, Precision, Recall, dan Specificity [12]. Nilai accuracy merupakan persentase jumlah record data yang dapat diklasifikasikan secara benar oleh sebuah algoritma. Perhitungan accuracy menggunakan Persamaan 11.

$A C C=\frac{T P+T N}{P+N}$

Dimana, $\mathrm{P}$ adalah jumlah record yang positif, dan $\mathrm{N}$ adalah jumlah record yang negatif.

$A C C=\frac{13+94}{18+99}$

$$
=0,91453 \times 100 \%=91,453 \%
$$

Nilai precision merupakan proporsi jumlah kasus yang diprediksi positif yang juga positif benar pada data yang sebenarnya. Perhitungan precision menggunakan Persamaan 12.

$$
\begin{aligned}
& \text { Precision }=\frac{T P}{T P+F P} \\
& \text { Precision }=\frac{13}{13+5} \\
& =0,72222 \times 100 \%=72,222 \%
\end{aligned}
$$

Recall merupakan proporsi jumlah kasus positif yang sebenarnya yang diprediksi positif secara benar. Perhitungan recall menggunakan Persamaan 13.

$$
\begin{aligned}
& \text { Recall }=\frac{T P}{T P+F N} \\
& \text { Recall }=\frac{13}{13+5} \\
& \quad=0,72222 \times 100 \%=72,222 \%
\end{aligned}
$$

Specificity merupakan proporsi jumlah kasus negatif yang sebenarnya yang diprediksi negatif secara benar. Perhitungan specificity menggunakan Persamaan 14. 


$$
\begin{aligned}
& \text { Specificity }=\frac{T N}{T N+F P} \\
& \text { Specificity }=\frac{99}{99+5} \\
& =0,95192 \times 100 \%=95,192 \%
\end{aligned}
$$

Nilai Accuracy hasil keputusan menggunakan metode terhadap hasil keputusan penyelenggara magang diperoleh sebesar $91,453 \%$ dengan Precision sebesar $72,222 \%$, Recall sebesar 72,222\%, dan Specificity sebesar 95,192\%.

\section{Kesimpulan}

Algoritma ARAS dengan pembobotan ROC melalui pendekatan Interpolasi Linier dapat diimplementasikan pada penyeleksian peserta magang. Kemiripan hasil antara hasil keputusan menggunakan metode dengan hasil keputusan penyelenggara magang sebesar $91,453 \%$ berdasarkan perhitungan accuracy dari Confusion Matrix. Nilai bobot yang diperoleh untuk masing-masing kriteria menggunakan pembobotan ROC, yaitu bobot untuk kriteria komunikasi adalah 0,33973, kriteria sikap adalah 0,21473, kriteria penampilan adalah 0,15223 , kriteria kecakapan adalah 0,11057, kriteria tinggi badan adalah 0,07932, kriteria strata kelulusan adalah 0,05432, kriteria nilai kelulusan adalah 0,03348, dan kriteria usia adalah 0,01563.

\section{Daftar Pustaka}

[1] Purba IR, Purnawan IKA, Sasmita IGMA, Sistem Antrean Pelayanan Medis Praktik Dokter Bersama Berbasis Web, Jurnal IImiah Merpati (Menara Penelitian Akademika Teknologi Informasi). 2016; 4(3): 248-258.

[2] Sarja NKPG, Githa DP, Dharmaadi IPA, Sistem Informasi Geografis Rekomendasi Objek Wisata Bali Menggunakan Metode TOPSIS, Jurnal IImiah Merpati (Menara Penelitian Akademika Teknologi Informasi). 2018; 6(2): 96-107.

[3] Permana IPI, Putra IKGD, Sasmita IGMA, Rancang Bangun Sistem Pilkades Menggunakan Teknologi Smart Card sebagai Kartu Pemilih, Lontar Komputer : Jurnal Ilmiah Teknologi Informasi. 2016; 7(2): 83-92.

[4] Sudipa IGI, Decision Support System dengan Metode AHP, SAW dan ROC untuk Penentuan Pemberian Beasiswa (Studi Kasus : STMIK STIKOM Indonesia), Jurnal Teknologi Informasi dan Komputer. 2018; 4(1): 18-30.

[5] Sureeyatanapas P, Comparison of Rank-based Weighting Methods for Multi-criteria Decision Making, KKU Engineering Journal. 2016; 43(S3): 376-379.

[6] Maulana C, Hendrawan A, Pinem APR, Pemodelan Penentuan Kredit Simpan Pinjam Menggunakan Metode Additive Ratio Assessment (ARAS), Pengembangan Rekayasa dan Teknologi. 2019; 15(1): 7-11.

[7] Sari A, Data Mining Memprediksi Minat Masyarakat Terhadap Asuransi Jiwa dengan Metode Interpolasi Linier, Jurnal Riset Komputer (JURIKOM). 2015; 2(6): 62-65.

[8] Morais DC, Almeida AT, Alencar LH, Clemente TRN, Cavalcanti CZB, PROMETHEEROC Model for Assessing the Readinesso of Technology for Generating Energy, Mathematical Problems in Engineering. 2015; 2015(1): 1-11.

[9] Utami RT, Andreswari D, Setiawan Y, Implementasi Metode Simple Additive Weighting (SAW) dengan Pembobotan Rank Order Centroid (ROC) dalam Pengambilan Keputusan untuk Seleksi Pengguna Jasa Leasing Mobil (Studi Kasus: PT. Multindo Auto Finance Cabang Bengkulu), Jurnal Rekursif. 2016; 4(2): 209-221.

[10] Zavadskas EK, Turskis Z, A New Additive Ratio Assessment (ARAS) Method in Multicriteria Decision-making, Technological and Economic Development of Economy. 2010; 16(2): 159-172.

[11] Socrates IGA, Akbar AL, Akbar MS, Optimasi Naïve Bayes dengan Pemilihan Fitur dan Pembobotan Gain Ratio, Lontar Komputer : Jurnal IImiah Teknologi Informasi . 2016; 7(1): 22-30.

[12] Mahendra GS, Aryanto KYE, SPK Penentuan Lokasi ATM Menggunakan Metode AHP dan SAW, Jurnal Nasional Teknologi dan Sistem Informasi. 2019; 5(1): 49-56. 